\title{
Epigenetic alterations in human brain tumors in a Brazilian population
}

\author{
Nilson Praia Anselmo ${ }^{1}$, Maria Josefa Bello², Pilar Gonzalez-Gomez ${ }^{2}$, Luis Antonio Araújo Dias ${ }^{3}$, \\ José Reinaldo Walter de Almeida ${ }^{4}$, Marcelo José dos Santos ${ }^{4}$, Juan A. Rey ${ }^{2}$ and Cacilda Casartelli ${ }^{5}$ \\ ${ }^{1}$ Laboratório de Biologia Molecular "Francisco Mauro Salzano”, Departamento de Genética, \\ Centro de Ciências Biológicas, Universidade Federal do Pará, Belém, PA, Brazil. \\ ${ }^{2}$ Laboratório de Oncogenética Molecular, Departamento de Cirurgia Experimental, \\ Hospital Universitário “La Paz”, Madrid, Espanha. \\ ${ }^{3}$ Setor de Neurocirurgia do Hospital Santa Casa de Misericórdia, Ribeirão Preto, SP, Brazil. \\ ${ }^{4}$ Fundação Pio XII, Hospital de Câncer de Barretos, Barretos, SP, Brazil. \\ ${ }^{5}$ Laboratório de Oncogenética, Departamento de Genética, Faculdade de Medicina de Ribeirão Preto, \\ Universidade de São Paulo, Ribeirão Preto, SP, Brazil.
}

\begin{abstract}
Aberrant methylation of $\mathrm{CpG}$ islands located in promoter regions represents one of the major mechanisms for silencing cancer-related genes in tumor cells. We determined the frequency of aberrant $\mathrm{CpG}$ island methylation for several tumor-associated genes: DAPK, MGMT, p14 ${ }^{A R F}, p 16^{N K 4 a}, T P 73, R B 1$ and TIMP-3 in 55 brain tumors, consisting of 26 neuroepithelial tumors, 6 peripheral nerve tumors, 13 meningeal tumors and 10 metastatic brain tumors. Aberrant methylation of at least one of the seven genes studied was detected in $83.6 \%$ of the cases. The frequencies of aberrant methylation were: $40 \%$ for $p 14^{A R F}, 38.2 \%$ for MGMT, $30.9 \%$ for, $p 16^{\text {INK4a }}, 14.6 \%$ for TP73 and for TIMP-3, $12.7 \%$ for $D A P K$ and $1.8 \%$ for RB1. These data suggest that the hypermethylation observed in the genes $p 14^{A R F}, M G M T$ and $p 16^{N K A a}$ is a very important event in the formation or progression of brain tumors, since the inactivation of these genes directly interferes with the cell cycle or DNA repair. The altered methylation rate of the other genes has already been reported to be related to tumorigenesis, but the low methylation rate of $R B 1$ found in tumors in our sample is different from that so far reported in the literature, suggesting that perhaps hypermethylation of the promoter is not the main event in the inactivation of this gene. Our results suggest that hypermethylation of the promoter region is a very common event in nervous system tumors.
\end{abstract}

Key words: brain tumors, epigenetics, methylation.

Received: March 11, 2005; Accepted: December 16, 2005.

\section{Introduction}

Current evidences suggest that epigenetic changes play an important role in the evolution of human cancers. $\mathrm{CpG}$ islands are 0.5 to $2.0 \mathrm{~kb}$ DNA regions rich in cytosine-guanine dinucleotides, present in the 5' region of approximately half of human genes (Baylin et al. 1998). Aberrant methylation occurs in tumor cell $\mathrm{CpG}$ islands as an important pathway for the repression of gene transcription of tumor-related genes, and this loss of gene expression contributes to the pathogenesis and progression of malignant neoplasms (Baylin et al. 1998).

Send correspondence to Nilson Praia Anselmo. Laboratório de Biologia Molecular "Francisco M. Salzano", Departamento de Genética, Centro de Ciências Biológicas, Universidade Federal do Pará, Rua Augusto Correa s/n, Guamá, 66075-900 Belém, PA, Brazil. E-mail: praia@ufpa.br.
Studies on methylation in nervous system tumors have shown that astrocytic tumors present several methylated genes (Burns et al., 1998; Nakamura et al., 1998, 2001a, 2001b; Esteller et al., 1999, 2000a; Park et al., 2000; Dong et al., 2001; Gonzalez-Gomez et al., 2003a, 2003b, 2003c). Epigenetic inactivation in non-astrocytic tumors is involved with several genes in oligodendrogliomas (Bortolotto et al., 2000; Wolter et al., 2001; Alonso et al., 2003). Watanabe et al. (2001a, 2001b) found that a simultaneous alteration in the interaction pathways $R B 1 / C D K 4 / p 16^{I N K 4 a}$, $p 15^{I N K 4 b}$ and that TP53/p14 $4^{A R F} / M D M 2$ is important in the development of the malignant phenotype of the anaplastic oligodendrogliomas. It was thus concluded that methylation is an important event in the formation of gliomas but, however, there are few studies of methylation in meningiomas (Tse et al., 1998; Boström et al., 2001), 
ependymomas (Alonso et al., 2003) and neuroblastomas (Gonzalez-Gomez et al., 2003d).

Yin et al. (2002) analyzed nervous system tumors of various subtypes and found that $28 \%$ of the sample investigated had at least one methylated gene and that TP53 and p $14^{A R F}$ presented a high frequency of genetic and epigenetic alterations, suggesting that those alterations must have an important role in the development of brain tumors. We determined the methylation profile for 55 brain tumors, studying seven genes that frequently show promoter region methylation in several neoplasms (breast, brain tumors, lung, gastric, colon cancer etc.). The genes were: deathassociated protein kinase $(D A P K), \mathrm{O}_{6}$-methyl-guanineDNA methyltransferase (MGMT), p14 $4^{A R F}, p 16^{I N K 4 a}, T P 73$, $R B 1$ and tissue inhibitor of metalloproteinase 3 (TIMP-3). These genes were selected for analysis based on their localization on genomic regions involved in chromosome deletions in brain tumors or the fact that they were known to have a key role in tumor development.

\section{Material and Methods}

\section{Tissue samples and DNA preparation}

Fresh brain-tumor tissue and blood samples were obtained from 25 women and 30 men $(n=55)$ Brazilian individuals whose age ranged from 10 to 77 years (mean $=50 \pm$ 17.3 years). These individuals were treated for brain cancers at Santa Casa Hospital in Ribeirão Preto city, Brazil. This study was approved by the Medical Ethics Committee of the University of São Paulo (FMRP-USP) and National Ethics Committee of Research (CONEP) and informed patient consent was also obtained. Pathological diagnosis was performed according to the WHO classification (Kleihues and Cavenee, 2000; Kleihues et al., 2002) as: 26 neuroepithelial tumors ( 8 astrocytomas, 10 glioblastomas, 1 neuroblastoma, 2 ependymomas and 5 oligodendrogliomas), 6 peripheral nerve tumors (schwannomas), 13 meningiomas and 10 metastatic tumors. DNA was prepared from frozen tissues and blood samples using standard methods (Rey et al., 1992).

\section{Bisulfite treatment of DNA and methylation-specific polymerase chain reaction (MSP)}

Bisulfite modification of genomic DNA was performed as reported by Herman et al. (1996) and MSP was used to examine methylation at the DAPK (located at 9q34.1), MGMT (at 10q26), p14 $4^{A R F}$ (at 9p21), p16 $6^{I N K 4 a}$ (at 9p21), TP73 (exon 1 - at 1p36.3), RB1 (at 13q14) and TIMP-3 (at 22q12.3) promoter regions. The primer sequences of these genes for the methylated and unmethylated reactions were as described by Gonzalez-Gomez et al. (2003d).

We used the following methodology: $2 \mu \mathrm{g}$ of genomic DNA was denatured with $\mathrm{NaOH}$, modified by treatment with sodium bisulfite, purified using the DNA clean-up kit (Promega, Madison, WI), treated again with $\mathrm{NaOH}$, precipitated with ethanol, and resuspended in water. Specific PCRs were performed for the methylated and unmethylated alleles under standard conditions with variable annealing temperatures $\left(55-66{ }^{\circ} \mathrm{C}\right)$. The PCR products were electrophoresed on either 2 to $3 \%$ agarose gels or non-denaturing $6 \%$ polyacrylamide gels, stained with ethidium bromide and visualized under UV illumination. Control reactions without DNA were performed for each PCR. For positive and negative controls for methylated alleles we used DNA from the lymphocytes of healthy volunteers, treated and untreated with Sss1 methyltransferase (New England Biolabs, Beverly, MA, USA) and then subjected to bisulfite treatment. Samples giving signals approximately equivalent to the positive control were designated as methylated. All experiments were repeated at least twice and the PCR for all samples demonstrating positive methylation for a specific gene was repeated at least three times to confirm these results.

\section{Statistics}

We used the methylation frequency (MF) defined as the number of individuals of the sample with methylated genes divided by the total number of individuals of the sample multiplied by 100 . We also used methylation index (MI) to determine the overall methylation rate in individual samples, the MI being defined as a fraction representing the number of methylated genes divided by the number of tested genes. Statistical analysis was performed using the chi-squared $\left(\chi^{2}\right)$ test and Fisher's exact test for differences between groups and the Student's t-test and Mann-Whitney test for differences between means.

\section{Results}

\section{Promoter methylation in all samples}

The MSP results for the 7 loci are shown in Tables 1 and 2 which summarize the promoter methylation of each gene in every tumor subtype analyzed. A total of 46 of 55 samples (83.6\%) displayed $\mathrm{CpG}$ island hypermethylation in at least one gene and the methylation frequency for each locus in this tumor series varied from 1.8 to $40 \%$, representative examples of the MSP analysis being shown in Figure 1. The highest promoter methylation frequency for the total number of tumors was $40 \%$ for the $p 14^{A R F}$ locus and the lowest $1.8 \%$ for the $R B 1$ locus , while the corresponding frequencies for gliomas were $68.8 \%$ for the $M G M T$ locus and $0 \%$ for the $R B 1$ locus, although it should be noted that individual tumors and gliomas showed higher methylation frequencies (Table 1).

The methylation index of multiple loci in a tumor series ranged from 0 to 0.71 (Table 2), with an overall mean of 0.22 and this table also shows that the neuroepithelial tumors displayed an overall mean of 0.25 , the tumors of peripheral nerve groups 0.14 , meningiomas 0.16 and the other 
Table 1 - Methylation of brain tumors, relationships between their histological characteristics and the degree of methylation presented by the different genes studied.

\begin{tabular}{|c|c|c|c|c|c|c|c|c|c|c|c|c|c|c|c|}
\hline \multirow{3}{*}{$\begin{array}{l}\text { Type of tumor or } \\
\text { glioma }\end{array}$} & \multirow[t]{3}{*}{ Number } & \multicolumn{14}{|c|}{ Methylation frequency of the genes analyzed } \\
\hline & & \multicolumn{2}{|c|}{$D A P K$} & \multicolumn{2}{|c|}{$M G M T$} & \multicolumn{2}{|c|}{$p 14^{A R F}$} & \multicolumn{2}{|c|}{$p 16^{I N K 4 a}$} & \multicolumn{2}{|c|}{$T P 73$} & \multicolumn{2}{|c|}{$R B 1$} & \multicolumn{2}{|c|}{$T I M P-3$} \\
\hline & & $\mathrm{N}$ & $\%$ & $\mathrm{~N}$ & $\%$ & $\mathrm{~N}$ & $\%$ & $\mathrm{~N}$ & $\%$ & $\mathrm{~N}$ & $\%$ & $\mathrm{~N}$ & $\%$ & $\mathrm{~N}$ & $\%$ \\
\hline \multicolumn{16}{|l|}{ Tumors } \\
\hline Neuroepithelial tumors & 26 & 4 & 15.4 & 15 & 57.7 & 9 & 34.6 & 7 & 26.9 & 5 & 19.2 & 0 & 0 & 6 & 23.1 \\
\hline Meningiomas & 13 & 1 & 7.7 & 1 & 7.7 & 8 & 61.5 & 3 & 23 & 2 & 15.4 & 0 & 0 & 0 & 0 \\
\hline Other tumors & 10 & 2 & 20 & 3 & 30 & 5 & 50 & 4 & 40 & 0 & 0 & 1 & 10 & 2 & 20 \\
\hline Total & 55 & 7 & 12.7 & 21 & 38.2 & 22 & 40 & 17 & 30.9 & 8 & 14.6 & 1 & 1.8 & 8 & 14.6 \\
\hline \multicolumn{16}{|l|}{ Sex } \\
\hline Males & 30 & 4 & 13 & 12 & 40 & 8 & 26.7 & 6 & 20 & 4 & 13 & 1 & 3 & 3 & 10 \\
\hline Females & 25 & 3 & 12 & 9 & 36 & 14 & 56 & 11 & 44 & 4 & 16 & 0 & 0 & 5 & 20 \\
\hline \multicolumn{16}{|l|}{ Age (years) } \\
\hline 50 years or less & 25 & 2 & 8 & 8 & 32 & 8 & 32 & 6 & 20 & 4 & 13 & 0 & 0 & 3 & 12 \\
\hline Over 50 years & 30 & 5 & 16.7 & 13 & 43.3 & 14 & 46 & 9 & 30 & 4 & 13.3 & 1 & 3.3 & 5 & 16.7 \\
\hline \multicolumn{16}{|l|}{ Gliomas } \\
\hline Astrocytomas & 8 & 1 & 12.5 & 4 & 50 & 3 & 37.5 & 3 & 37.5 & 1 & 12.5 & 0 & 0 & 3 & 37.5 \\
\hline Glioblastomas & 10 & 1 & 10 & 7 & 70 & 3 & 30 & 1 & 10 & 4 & 40 & 0 & 0 & 2 & 20 \\
\hline Oligodendrogliomas II & 2 & 1 & 50 & 1 & 50 & 1 & 50 & 1 & 50 & 0 & 0 & 0 & 0 & 0 & 0 \\
\hline $\begin{array}{l}\text { Anaplastic } \\
\text { Oligodendrogliomas }\end{array}$ & 3 & 2 & 66.6 & 1 & 33.3 & 1 & 33.3 & 1 & 33.3 & 0 & 0 & 0 & 0 & 0 & 0 \\
\hline Ependymomas & 2 & 2 & 50 & 0 & 0 & 1 & 50 & 1 & 50 & 0 & 0 & 0 & 0 & 1 & 50 \\
\hline
\end{tabular}

$\mathrm{N}$ : Number.

brain tumors groups 0.25 . No statistical differences were found in the methylation rate when DAPK, $16^{I N K 4 a}, T P 73$ and $R B 1$ loci were analyzed in the groups of tumors studied ( $\mathrm{p}>0.05$ ) but the $M G M T$ locus showed highly significant results $(\mathrm{p}<0.05)$ when the epithelial tumors were compared to meningiomas (Fisher's test $=0.00004$, significant at $p=0.05$ ) and significant when epithelial tumors were compared to other tumor types (Fisher's test $=0.01754$, significant at $\mathrm{p}=0.05$ ). The $p 14^{A R F}$ locus showed no significant differences when the meningiomas and epithelial tumors were compared to others tumors types. However a highly significant difference for this locus was observed after comparison between peripheral nerve tumors and meningiomas (Fisher's test $=0.00052$, significant at $p=0.05$ ) or peripheral nerve tumors and others tumors types (Fisher's test $=0.00478$, significant at $p=0.05$ ). The TIMP-3 locus showed significant results when epithelial tumors were compared to meningiomas (Fisher's test $=0.00668$, significant at $\mathrm{p}=0.05$ ) and the meningiomas were compared with other tumor types (Fisher's test $=0.03112$, significant at $p=0.05$ ). No significant association could be determined between the methylation status of each locus and data on the age and sex of the patients, the overall MI value for patients aged 50 or less was 0.26 and over 50 years 0.19 (not significant by the Student's t-test at $\mathrm{p}>0.05$ ) while the overall MI values grouped according to sex were 0.19 for males and 0.26 females (not significant by the Student's t-test at $\mathrm{p}>0.05$ ) (Tables 1 and 2).

\section{Promoter methylation in the glioma sample}

Regarding promoter methylation in the gliomas investigated (excluding ependymomas and neuroblastomas), we found that a total of 18 of the 23 samples $(83.6 \%)$ displayed $\mathrm{CpG}$ island hypermethylation in at least one gene (Tables 1 and 2). The frequency of methylation among the genes ranged from 0 for the $R B 1$ locus to $60.8 \%$ for the $M G M T$ locus, although again it should be noted that individual types of gliomas showed higher methylation frequencies (Table 1). There was a significant difference (Fisher's test $=0.028$, significant at $\mathrm{p}=0.05$ ) for the TP73 locus when oligodendrogliomas were compared to glioblastomas but all the other gliomas and genes showed no significant differences $(\mathrm{p}<0.05)$, although when astrocytomas and oligodendrogliomas where compared regarding the TIMP-3 gene the probability value was very close to the 
Table 2 - Summary of methylation of all seven genes in brain tumors. Filled boxes represent methylated loci and open boxes unmethylated loci. M=Male Sex; F = Female Sex.

\begin{tabular}{|c|c|c|c|c|c|c|c|c|c|}
\hline \multirow[t]{2}{*}{ Histopathologic diagnosis } & \multirow[t]{2}{*}{ Age/Sex } & \multicolumn{7}{|c|}{ Genes } & \multirow{2}{*}{$\begin{array}{l}\text { Methylation } \\
\text { index }\end{array}$} \\
\hline & & $D A P K$ & $M G M T$ & $p 14^{A R F}$ & $p 16^{I N K}$ & $T P 73$ & $R B 1$ & TIMP3 & \\
\hline Astrocytoma - $\mathrm{SN}_{38}$ & $46 / \mathrm{M}$ & & & & & & & & 0.57 \\
\hline Astrocytoma - $\mathrm{SN}_{58}$ & $71 / \mathrm{F}$ & & & & & & & & 0.43 \\
\hline Anaplasic astrocytoma - $\mathrm{SN}_{66}$ & $27 / \mathrm{M}$ & & & & & & & & 0.00 \\
\hline Anaplasic astrocytoma - $\mathrm{SN}_{16}$ & $30 / \mathrm{M}$ & & & & & & & & 0.14 \\
\hline Giant Cell astrocytoma - $\mathrm{SN}_{49}$ & $14 / \mathrm{M}$ & & & & & & & & 0.00 \\
\hline Pilocytic astrocytoma - $\mathrm{SN}_{05}$ & $24 / \mathrm{M}$ & & & & & & & & 0.14 \\
\hline Pilocytic astrocytoma - $\mathrm{SN}_{35}$ & $62 / \mathrm{F}$ & & & & & & & & 0.57 \\
\hline Pilocytic astrocytoma - $\mathrm{SN}_{53}$ & $10 / \mathrm{M}$ & & & & & & & & 0.29 \\
\hline Glioblastoma multiforme - $\mathrm{SN}_{11}$ & $68 / \mathrm{M}$ & & & & & & & & 0.14 \\
\hline Glioblastoma multiforme - $\mathrm{SN}_{12}$ & $59 / \mathrm{F}$ & & & & & & & & 0.43 \\
\hline Glioblastoma multiforme - $\mathrm{SN}_{36}$ & $72 / \mathrm{F}$ & & & & & & & & 0.29 \\
\hline Glioblastoma multiforme - $\mathrm{SN}_{40}$ & $65 / \mathrm{M}$ & & & & & & & & 0.57 \\
\hline Glioblastoma multiforme - $\mathrm{SN}_{41}$ & $51 / \mathrm{M}$ & & & & & & & & 0.29 \\
\hline Glioblastoma multiforme - $\mathrm{SN}_{47}$ & $50 / \mathrm{F}$ & & & & & & & & 0.43 \\
\hline Glioblastoma multiforme - $\mathrm{SN}_{51}$ & $68 / \mathrm{M}$ & & & & & & & & 0.14 \\
\hline Glioblastoma multiforme - $\mathrm{SN}_{56}$ & $56 / \mathrm{M}$ & & & & & & & & 0.14 \\
\hline Glioblastoma multiforme - $\mathrm{SN}_{61}$ & $65 / \mathrm{M}$ & & & & & & & & 0.14 \\
\hline Glioblastoma multiforme - $\mathrm{SN}_{70}$ & $45 / \mathrm{M}$ & & & & & & & & 0.00 \\
\hline Oligodendroglioma - $\mathrm{SN}_{26}$ & $33 / \mathrm{M}$ & & & & & & & & 0.00 \\
\hline Oligodendroglioma - $\mathrm{SN}_{30}$ & $58 / \mathrm{M}$ & & & & & & & & 0.57 \\
\hline Anaplasic oligodendroglioma - $\mathrm{SN}_{14}$ & $37 / M$ & & & & & & & & 0.14 \\
\hline Anaplasic oligodendroglioma $-\mathrm{SN}_{18}$ & $37 / \mathrm{F}$ & & & & & & & & 0.43 \\
\hline Anaplasic oligodendroglioma - $\mathrm{SN}_{27}$ & $52 / \mathrm{M}$ & & & & & & & & 0.00 \\
\hline Ependymoma - $\mathrm{SN}_{29}$ & $48 / \mathrm{F}$ & & & & & & & & 0.43 \\
\hline Ependymoma - $\mathrm{SN}_{42}$ & $53 / \mathrm{M}$ & & & & & & & & 0.14 \\
\hline Olfatory Neuroblastoma - $\mathrm{SN}_{06}$ & $64 / \mathrm{M}$ & & & & & & & & 0.14 \\
\hline Schwannoma - $\mathrm{SN}_{15}$ & $38 / \mathrm{F}$ & & & & & & & & 0.14 \\
\hline Schwannoma - $\mathrm{SN}_{17}$ & $37 / \mathrm{F}$ & & & & & & & & 0.14 \\
\hline Schwannoma - $\mathrm{SN}_{19}$ & $37 / \mathrm{F}$ & & & & & & & & 0.14 \\
\hline Schwannoma - $\mathrm{SN}_{20}$ & $49 / \mathrm{F}$ & & & & & & & & 0.29 \\
\hline Schwannoma - $\mathrm{SN}_{57}$ & $60 / \mathrm{F}$ & & & & & & & & 0.14 \\
\hline Schwannoma - $\mathrm{SN}_{60}$ & $31 / \mathrm{M}$ & & & & & & & & 0.00 \\
\hline Meningioma - $\mathrm{SN}_{04}$ & $63 / \mathrm{F}$ & & & & & & & & 0.14 \\
\hline Meningioma $-\mathrm{SN}_{13}$ & $31 / \mathrm{M}$ & & & & & & & & 0.29 \\
\hline Meningioma - $\mathrm{SN}_{23}$ & $64 / \mathrm{F}$ & & & & & & & & 0.00 \\
\hline Meningioma - $\mathrm{SN}_{24}$ & $41 / \mathrm{F}$ & & & & & & & & 0.29 \\
\hline Meningioma - $\mathrm{SN}_{31}$ & $68 / \mathrm{F}$ & & & & & & & & 0.14 \\
\hline Meningioma $-\mathrm{SN}_{33}$ & $45 / \mathrm{F}$ & & & & & & & & 0.14 \\
\hline Meningioma - $\mathrm{SN}_{39}$ & $57 / \mathrm{M}$ & & & & & & & & 0.14 \\
\hline Meningioma $-\mathrm{SN}_{46}$ & $55 / \mathrm{F}$ & & & & & & & & 0.14 \\
\hline Meningioma - $\mathrm{SN}_{59}$ & $75 / \mathrm{F}$ & & & & & & & & 0.14 \\
\hline Meningioma - $\mathrm{SN}_{64}$ & $61 / \mathrm{F}$ & & & & & & & & 0.14 \\
\hline Meningioma - $\mathrm{SN}_{68}$ & $71 / \mathrm{F}$ & & & & & & & & 0.14 \\
\hline Meningioma - $\mathrm{SN}_{72}$ & $57 / \mathrm{F}$ & & & & & & & & 0.14 \\
\hline Atypical meningioma - $\mathrm{SN}_{32}$ & $22 / \mathrm{M}$ & & & & & & & & 0.29 \\
\hline Metastatic tumor - $\mathrm{SN}_{43}$ & $77 / \mathrm{M}$ & & & & & & & & 0.14 \\
\hline Metastatic tumor $-\mathrm{SN}_{45}$ & $69 / \mathrm{F}$ & & & & & & & & 0.71 \\
\hline Metastatic tumor $-\mathrm{SN}_{54}$ & $50 / \mathrm{M}$ & & & & & & & & 0.14 \\
\hline Metastatic tumor $-\mathrm{SN}_{63}$ & $62 / \mathrm{M}$ & & & & & & & & 0.43 \\
\hline Metastatic tumor $-\mathrm{SN}_{71}$ & $41 / \mathrm{M}$ & & & & & & & & 0.00 \\
\hline Metastatic tumor $-\mathrm{SN}_{28}$ & $60 / \mathrm{M}$ & & & & & & & & 0.14 \\
\hline Metastatic tumor $-\mathrm{SN}_{48}$ & $55 / \mathrm{F}$ & & & & & & & & 0.43 \\
\hline Metastatic tumor $-\mathrm{SN}_{50}$ & $73 / \mathrm{F}$ & & & & & & & & 0.00 \\
\hline Metastatic tumor $-\mathrm{SN}_{55}$ & $24 / \mathrm{M}$ & & & & & & & & 0.29 \\
\hline Metastatic tumor $-\mathrm{SN}_{69}$ & $11 / \mathrm{M}$ & & & & & & & & 0.14 \\
\hline
\end{tabular}




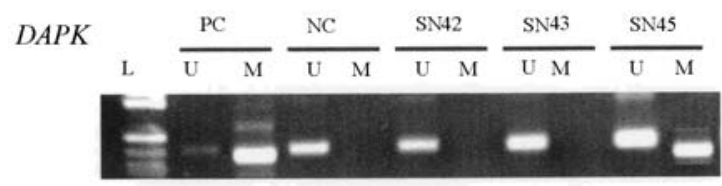

MGMT

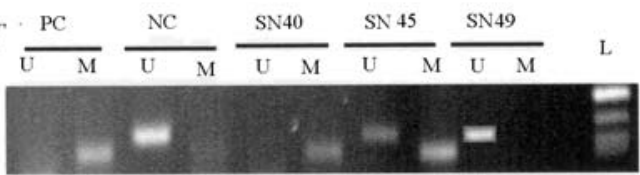

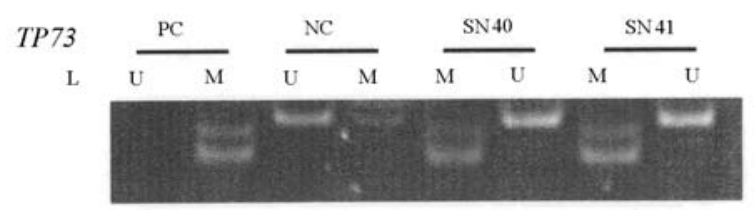

TIMP - 3

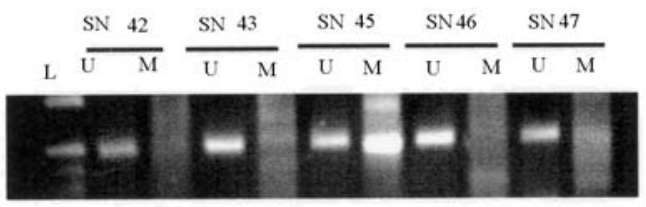

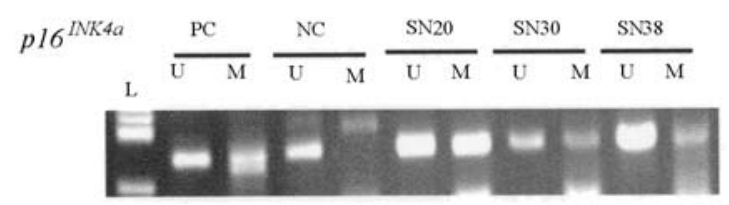
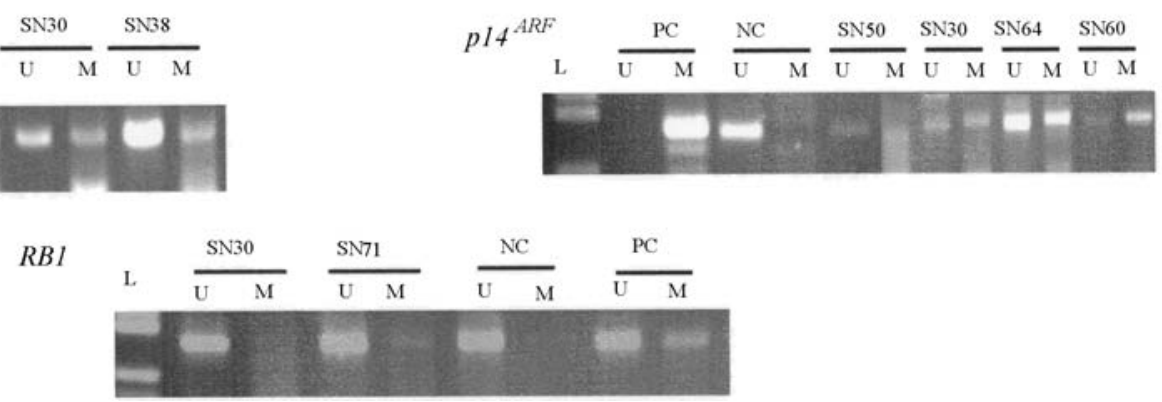

Figure 1 - Methylation analysis by MSP in brain tumors. The studied gene is given on the left of each panel. Lane U = amplified product with primers recognizing unmethylated sequences; Lane $\mathrm{M}=$ amplified product with primers recognizing methylated sequences. PC $=$ positive control (DNA treated with methylase); $\mathrm{NC}=$ negative control (DNA of non malignant tissue); $\mathrm{L}=$ ladder.

significance limit (Fisher's test $=0.535$, no significant at $\mathrm{p}=0.05)$.

The MI ranged from 0 to 0.57 , with a mean of 0.25 . When the three types of gliomas were considered the means were 0.27 for astrocytomas, 0.25 for glioblastomas and 0.23 for oligodendrogliomas (Table 2).

\section{Discussion}

This study of 55 brain tumors and gliomas investigated the methylation status of a set of loci which have been identified as frequently methylated in other cancers or cell lines. Moreover, the chosen loci are located at genomic regions involved in chromosomal deletions in brain tumors (TP73 at $1 \mathrm{p} ; p 14^{A R F}$ and $p 16^{I N K 4 a}$ at 9p) or they play key tumor-related functions (RB1, MGMT etc.). Transcriptional silencing by hypermethylation of $\mathrm{CpG}$ islands in the promoter regions is accepted as a primary mechanism involved in the inactivation of tumor-related genes (Esteller et al., 2001a; Esteller and Herman, 2002).

Our study of seven genes shows that hypermethylation is variable according to the gene. The highest methylation frequencies were detected for the $p 14^{A R F}, M G M T$ and p1 $6^{I N K 4 a}$ genes and intermediate frequencies for the TP73, $T I M P-3$ and $D A P K$ genes and low frequencies for the $R B 1$ gene.

The high methylation frequency of genes $p 14^{A R F}$, MGMT and $p 16^{I N K 4 a}$ agree with several previous studies (Costello et al., 1996; Dong et al., 2001; Gonzalez-Gomez et al., 2003b, 2003c, 2003d) and it is known that the $p 14^{A R F}$ and $p 16^{I N K 4 a}$ genes are located very close to each other at 9p21 and share an exon, albeit in another reading frame (Sherr, 1996). The transcriptional activity of the $p 14^{A R F}$ gene is regulated independently of the $p 16^{I N K 4 a}$ gene, the p $14^{A R F}$ gene participating in an autoregulatory feedback loop involving p53 and MDM2 (Robertson and Jones, 1998). Methylation studies of these genes have produced variable results. Yin et al. (2002) found methylation of $p 14^{A R F}$ in $18 \%$ of the brain tumors studied by them but a significantly low methylation of this gene in gliomas, p $16^{I N K 4 a}$ being methylated in only $7 \%$ of the total and $6 \%$ of gliomas. Alonso et al. (2003) studied a series of oligodendrogliomas and found that $44 \%$ of $p 14^{A R F}$ genes and $22 \%$ of p1 $6^{I N K 4 a}$ genes were methylated. Dong et al. (2001) found that $2 \%$ of $p 14^{A R F}$ genes and $12 \%$ of $p 16^{I N K 4 a}$ genes were methylated, while Wolter et al. (2001) reported that $21 \%$ of $p 14^{A R F}$ genes were methylated in grade II oligodendrogliomas and $15 \%$ of the same genes were methylated in anaplastic oligodendrogliomas while only one sample of their series showed aberrant methylation of $p 16^{I N K 4 a}$. In our sample $40 \%$ of $p 14^{A R F}$ genes and $30.9 \%$ of $p 16^{I N K 4 a}$ genes were methylated when considering tumors and gliomas together but when considering gliomas on their own only $34.8 \%$ of $p 14^{A R F}$ genes and $26.1 \%$ of $p 16^{I N K 4 a}$ were methylated. We also observed that both genes were methylated in $26.9 \%$ of the neuroepithelial tumors. Although our sample of oligodendroglial tumors was small both genes were 
methylated in $50 \%$ of the oligodendrogliomas and $33.3 \%$ of the anaplastic oligodendrogliomas, showing a frequency pattern similar to that described by other authors. We also found that in meningiomas $61.5 \%$ of $p 14^{A R F}$ genes and $23 \%$ of $p 16^{I N K 4 a}$ were methylated but in schwannomas only the p16 ${ }^{I N K 4 a}$ gene was methylated.

These data are similar to the results reported by Yin et al. (2002), with other data showing a moderate to high methylation frequency in neuroepithelial tumors (Merlo et al., 1995; Nishikawa et al., 1995; Costello et al., 1996, 2000; Dong et al., 2001; Wolter et al., 2001; Yin et al., 2002; Alonso et al., 2003 Gonzalez-Gomez et al., 2003b, $2003 \mathrm{c}, 2003 \mathrm{~d}$ ) but a low frequency in meningeal tumors (Park et al., 2000; Boström et al., 2001), although methylation studies in nervous system tumors are still rare.

Yin et al. (2002) found a higher frequency of methylation in $p 14^{A R F}$ than in $p 16^{I N K 4 a}$ in the meningiomas and that $p 14^{A R F}$ was not methylated in the schwannomas. Our data showed the same results, indicating that in these tumors there is preferential methylation of one gene as opposed to the other. Theses results support the idea that inactivation by hypermethylation of $p 14^{A R F}$ and/or $p 16^{I N K 4 a}$ is an important mechanism in the development of brain tumors because the inactivation of $p 14^{A R F}$ by epigenetic mechanisms may interfere with the network of TP53 interactions (Zhang et al., 1998; Esteller et al., 2000b, 2001a, 2001b; Amatya et al., 2005).

Our data show that the $M G M T$ gene has a high rate of methylation (38.2\%), agreeing with other reports (Dong et al., 2001; Esteller et al., 2001a; Alonso et al., 2003). It is known that $M G M T$ is a DNA repair gene, and it has been proposed that silencing the gene through promoter hypermethylation confers on the cancer cells an additional mutational capacity. It was proposed that the methylation of this gene is a factor in the transitory mutation of TP53 (Esteller et al., 1999). Brell et al. (2005) suggested that the absence of $M G M T$ expression is a positive predictive marker in patients with anaplastic glioma. Epigenetic silencing of this gene by promoter methylation compromises DNA repair and has been associated with longer survival in patients with glioblastoma who receive alkylating agents (Hegi et al., 2005; Esteller et al., 2000a). Nakamura et al. (2001c) found that MGMT methylation was more frequent (75\%) in secondary glioblastomas, which progressed from low degree astrocytomas, than in primary glioblastomas $(36 \%$ $M G M T$ methylation) and also verified that there was a possible association between methylation of this gene and alterations in the TP53 gene. Esteller (2000) observed that $40 \%$ of gliomas but none of the meningiomas studied had the promoter region of the $M G M T$ gene hypermethylated, suggesting that $M G M T$ might play a key role in tumorigenesis, as its inactivation causes several nucleotide changes in the genomic DNA. In our sample we found that the $M G M T$ gene was methylated in $57.7 \%$ of gliomas and $7.7 \%$ of meningiomas. The differences between the me- thylation frequencies observed for gliomas and meningiomas in the present investigation are highly significant (Fisher's test $=0.0004$, significant at $\mathrm{p}=0.05$ ), supporting the data previously reported. Even so, more studies are necessary to try to elucidate the role of this gene in the formation of these tumors.

A low TP53 mutation rate was found in our sample (Anselmo et al., unpublished data) leading us to suppose that the methylation of the $M G M T$ and $p 14^{A R F}$ genes might be one of the alternative mechanisms involved in the inactivation of TP53, one of the tumor suppressor genes most involved in carcinogenesis (Zhang et al., 1998; Yin et al., 2002; Amatya et al., 2005). The TP73 gene was highly conserved in our sample, with only one conformational alteration being found (Anselmo et al., unpublished data), agreeing with previously published reports (Alonso et al., 2001a, 2001b; Lomas et al., 2001). These findings suggest that epigenetic mechanisms are involved in the inactivation of the TP73 gene (Corn et al., 1999; Banelli et al., 2000; Alonso et al., 2001a, 2001b; Dong et al., 2001; Gonzalez-Gomez et al., 2003b, 2003c, 2003d; Lomas et al., 2004). The methylation rate of the sample analyzed by us agrees with other results, which described a variable rate of TP73 methylation (Dong et al., 2001; Esteller et al., 2001a; Alonso et al., 2003; Gonzalez-Gomez et al., 2003b, 2003c, 2003d). However, additional studies are necessary to elucidate the role of this gene in brain tumor carcinogenesis.

We found that in our sample the TIMP-3 gene was moderately methylated $(14.6 \%)$, while in the literature a high degree of methylation has been reported for neuroepithelial tumors (Bachman et al., 1999; Alonso et al., 2001a, 2001b; Gonzalez-Gomez et al., 2003b, 2003c, 2003d). This gene is necessary to suppress tissue remodeling, angiogenesis, invasion and metastasis (Bachman et al., 1999). However, we did not find any methylation of the TIMP-3s gene in meningiomas. Bello et al. (2004) showed aberrant methylation of TIMP-3 with statistical significance in $18 \%$ of grade I tumors versus $40 \%$ of grade II - III meningiomas. It has been suggested that the aberrantly methylated TIMP-3 occurring in the low-grade forms of some histological subtypes of brain tumors may indicate that this epigenetic change occurs early during brain tumor progression (Bello et al., 2004) however no methylation of this gene was observed in the meningiomas studied by us. With regard to the gliomas our results were weakly significant $(p=0.049)$ as compared with pilocytic astrocytomas and schwannomas. However, our sample was relatively small and there are few studies regarding these neoplasms, so more data are needed to confirm if the inactivation of this gene by methylation is an important event in the tumorigenesis of these tumors. In fact, $18 \%$ of TIMP-3 aberrant methylation has previously been described in schwannomas (Gonzalez-Gomez et al., 2003e).

The protein coded by $D A P K$ is possibly a mediator of apoptosis induced by IFN $\gamma$ and is considered as a potential 
metastasis inhibitor gene (Sanchez-Cespedes et al., 2000). A significant increase in the rate of methylation of the $D A P K$ gene has been reported in oligodendrogliomas, when grade II and grade III tumors were compared, suggesting that this gene may be involved in the progression of gliomas (Dong et al., 2001; Alonso et al., 2001a). We found $12.7 \%$ of the cases methylated, in agreement with the literature (Alonso et al., 2001a, 2001b; Dong et al., 2001; Gonzalez-Gomez et al., 2003b, 2003c, 2003d), indicating that a certain degree of methylation of this gene occurs in neuroepithelial tumors. Schwannomas did not present methylation in our sample and only $4.5 \%$ ( 2 of 44 cases) in a previous tumor study (Gonzalez-Gomez et al., 2003e).

The $R B 1$ gene is one of the genes which play key roles in cell cycle control or apoptosis (Sherr, 1996). Our data show a very low rate of methylation of $R B 1(1.8 \%)$, agreeing with the data of Yin et al. (2002) who suggested that this gene probably does not play an important role in the development of most brain tumors. The state of methylation of this gene is very variable in the diverse tumor types, being hypermethylated in retinoblastomas, glioblastomas, pituitary adenomas and oligodendrogliomas but unmethylated in some cases of leukemia (Sakai et al., 1991; Greger et al., 1994; Ohtani-Fujita et al., 1997; Stirzaker et al., 1997; Melki et al., 1999; Simpson et al., 2000; Nakamura et al., 2001a; Gonzalez-Gomez et al., 2003a). One of the main checkpoints in the control of cell proliferation occurs between the $\mathrm{G} 1 \rightarrow \mathrm{S}$ phases of the cell cycle and involves the RB and p16 proteins, loss of activity of which may cause disturbance in cell growth regulation which leads to altered cell growth. In this study, we observed that the p16 genes were hypermethylated suggesting that the signaling pathway controlled by this protein could be altered. The alteration in this control pathway has already been observed in many different tumor types (Debbas and White, 1993; Morgenbesser et al., 1994; Tse et al., 1998; Dong et al., 2001).

For almost all the genes analyzed the majority of our results are similar to those reported in the literature. The conservation of the TP53 and TP73 genes found in our samples (Anselmo et al., unpublished data) suggests that the regulation of these genes occurs through another pathway, since we observed a significant degree of methylation in the $M G M T, p 14^{A R F}, p 16^{I N K 4 a}$ genes which may have a key role in the regulation of both TP53 and RB1, which were extremely conserved in our material.

There is a possible involvement of the $p 16^{I N K 4 a}$ gene in the formation of schwannomas and of $p 14^{A R F}$ in the formation of meningiomas, but more detailed studies are necessary.

The processes of gene inactivation by methylation do not occur in only one gene, but may occur simultaneously in a great number of genes which are often located on several chromosomes (Dong et al., 2001). We may conclude that the frequency of methylation varies according to the gene and/or the type of tumor.
Possible insights into the origins of brain tumors, as well as the possibility of improving treatment are coming to light from correlative studies of several parameters that have examined the relationships between specific types of tumors and their genetic signatures. For example, some studies have shown that oligodendrogliomas harboring allelic loss of $1 \mathrm{p}$ and $19 \mathrm{q}$ were significantly more likely to be located in the frontal lobes or bilaterally than tumors with intact alleles, which predominated in the temporal lobes and diencephalon, the 'older' and deeper region of the brain (Zlatescu et al., 2001; Mueller et al., 2002), suggesting a link between the origins of oligodendrogliomas and the molecular regulation of brain development. Other studies have described an association between imaging features and tumor genotype (Cairncross, 2004, Walker et al., 2004). Some benefits from agents used in chemotherapy are related to methylation of some genes in gliomas (Brell et al., 2005, Hegi et al., 2005). Molecular genetic markers introduce important new considerations into the design and interpretation of clinical trials for some tumors and are beginning to influence treatment strategies for individual patients stricken with neoplasias. A detailed knowledge of the alterations occurring in specific tumor types allied to the use of molecular testing and other clinical and pathological criteria for refining diagnoses and perhaps individualize therapy, associated with interdisciplinary studies may shed new light on the importance of molecular markers as decisive therapeutic factors.

In conclusion, we have examined $\mathrm{CpG}$ island methylation in brain tumors by analyzing the methylation status of 7 genes using MSP. We found that $\mathrm{CpG}$ island methylation is a relatively frequent event in these neoplasms and also that it sometimes occurred during the early stages of carcinogenesis and may be already present in the low-grade forms of these neoplasms. The frequency and timing of hypermethylation varied according to the gene and concordant inactivation of some genes appears to contribute to the carcinogenesis of some of these tumors.

\section{Acknowledgments}

Support for this work was provided by the Brazilian agencies FAPESP, CNPq, CAPES, FAEPA, UFPA and by the Programa de Cooperación Científica con Iberoamérica from Ministério de Educación (Spain), Agencia Española de Cooperación Científica con Iberoamérica and Hospital La Paz. We also thank: Vanderci Massaro de Oliveira, Márcio Rogério Penha, Eva Alonso, Jesus Lomas, Dolores Arjona.

\section{References}

Alonso ME, Bello MJ, Gonzalez-Gomez P, Lomas J, Arjona D, de Campos JM, Kusak ME, Sarasa JL, Isla A and Rey JA (2001a) Mutation analysis of the $p 73$ gene in nonastrocytic brain tumours. Br J Cancer 85:204-208. 
Alonso ME, Bello MJ, Lomas J, Gonzalez-Gomez P, Arjona D, De Campos JM, Gutierrez M, Isla A, Vaquero J and Rey JA (2001b) Absence of mutation of the $p 73$ gene in astrocytic neoplasms. Int J Oncol 19:609-612.

Alonso ME, Bello MJ, Gonzalez-Gomez P, Arjona D, Lomas J, De Campos JM, Isla A, Sarasa JL and Rey JA (2003) Aberrant promoter methylation of multiple genes in oligodendrogliomas and ependymomas. Cancer Genet Cytogenet 144:134-142.

Amatya VJ, Naumann U, Weller M and Ohgaki H (2005) TP53 promoter methylation in human gliomas. Acta Neuropathol 110:178-184.

Bachman KE, Herman JG, Corn PG, Merlo A, Costello JF, Cavenee WK, Baylin SB and Graff JR (1999) Methylationassociated silencing of the tissue inhibitor of metalloproteinase-3 gene suggest a suppressor role in kidney, brain, and other human cancers. Cancer Res 59:798-802.

Banelli B, Casciano I and Romani M (2000) Methylationindependent silencing of the $p 73$ gene in neuroblastoma. Oncogene 19:4553-4556.

Baylin SB, Herman JG, Graff JR, Vertino PM and Issa JP (1998) Alterations in DNA methylation: A fundamental aspect of neoplasia. Adv Cancer Res 72:141-196.

Bello MJ, Aminoso C, Lopez-Marin I, Arjona D, GonzalezGomez P, Alonso ME, Lomas J, de Campos JM, Kusak ME, Vaquero J, Isla A, Gutierrez M, Sarasa JL and Rey JA (2004) DNA methylation of multiple promoter-associated $\mathrm{CpG}$ islands in meningiomas: Relationship with the allelic status at $1 p$ and 22q. Acta Neuropathol 108:413-421.

Bortolotto S, Chiado-Piat L, Cavalla P, Bosone I, Chio A, Mauro A and Schiffer D (2000) CDKN2A/p16 inactivation in the prognosis of oligodendrogliomas. Int J Cancer 88:554-557.

Boström J, Meyer-Puttlitz B, Wolter M, Blaschke B, Weber RG, Lichter P, Ichimura K, Collins VP and Reifenberger G (2001) Alterations of the tumor suppressor genes CDKN2A (p16(INK4a)), p14(ARF),CDKN2B (p15(INK4b)), and $C D K N 2 C(p 18(\mathrm{INK} 4 c))$ in atypical and anaplastic meningiomas. Am J Pathol 159:661-669.

Brell M, Tortosa A, Verger E, Gil JM, Vinolas N, Villa S, Acebes JJ, Caral L, Pujol T, Ferrer I, Ribalta T and Graus F (2005) Prognostic significance of O6-Methylguanine-DNA methyltransferase determined by promoter hypermethylation and immunohistochemical expression in anaplastic gliomas. Clin Cancer Res 11:5167-5174.

Burns KL, Ueki K, Jhung SL, Koh J and Louis DN (1998) Molecular genetic correlates of $p 16, C D K 4$, and $p R b$ immunohistochemistry in glioblastomas. J Neuropathol Exp Neurol $57: 122-130$

Cairncross JG (2004) Imaging molecular signatures in oligodendroglioma. Clin Cancer Res 10:7182-7191.

Corn PG, Kuerbitz SJ, van Noesel MM, Esteller M, Compitello N, Baylin SB and Herman JG (1999) Transcriptional silencing of the $p 73$ gene in acute lymphoblastic leukemia and Burkitt's lymphoma is associated with $5, \mathrm{CpG}$ island methylation. Cancer Res 59:3352-3356.

Costello JF, Berger MS, Huang HS and Cavenee WK (1996) Silencing of $p 16 / C D K N 2$ expression in human gliomas by methylation and chromatin condensation. Cancer Res 56:2405-2410.
Costello JF, Plass C and Cavenee WK (2000) Aberrant methylation of genes in low-grade astrocytomas. Brain Tumor Pathol 17:49-56.

Debbas M and White E (1993) Wild-type $p 53$ mediates apoptosis by E1A, which is inhibited by E1B. Genes Dev 7:546-554.

Dong SM, Pang JC, Poon WS, Hu J, To KF, Chang AR and Ng HK (2001) Concurrent hypermethylation of multiple genes is associated with grade of oligodendroglial tumors. J Neuropathol Exp Neurol 60:808-816.

Esteller M (2000) Epigenetic lesions causing genetic lesions in human cancer: Promoter hypermethylation of DNA repair genes. Eur J Cancer 36:2294-2300.

Esteller M and Herman JG (2002) Cancer as an epigenetic disease: DNA methylation and chromatin alterations in human tumours. J Pathol 196:1-7.

Esteller M, Hamilton SR, Burger PC, Baylin SB and Herman JG (1999) Inactivation of the DNA repair gene O6-methylguanine-DNA methyltransferase by promoter hypermethylation is a common event in primary human neoplasia. Cancer Res 59:793-797.

Esteller M, Garcia-Foncillas J, Andion E, Goodman SN, Hidalgo OF, Vanaclocha V, Baylin SB and Herman JG (2000a) Inactivation of the DNA-repair gene MGMT and the clinical response of gliomas to alkylating agents. N Engl J Med 343:1350-1354.

Esteller M, Tortola S, Toyota M, Capella G, Peinado MA, Baylin SB and Herman JG (2000b) Hypermethylation-associated inactivation of $p 14(A R F)$ is independent of p16(INK4a) methylation and $p 53$ mutational status. Cancer Res 60:12933.

Esteller M, Corn PG, Baylin SB and Herman JG (2001a) A gene hypermethylation profile of human cancer. Cancer Res 61:3225-3229.

Esteller M, Cordon-Cardo C, Corn PG, Meltzer SJ, Pohar KS, Watkins DN, Capella G, Peinado MA, Matias-Guiu X, Prat J, Baylin SB and Herman JG (2001b) p14ARF silencing by promoter hypermethylation mediates abnormal intracellular localization of MDM2. Cancer Res 61:2816-2821.

Gonzalez-Gomez P, Bello MJ, Alonso ME, Arjona D, Lomas J, de Campos JM, Isla A and Rey JA (2003a) CpG island methylation status and mutation analysis of the $R B 1$ gene essential promoter region and protein-binding pocket domain in nervous system tumours. Br J Cancer 88:109-114.

Gonzalez-Gomez P, Bello MJ, Arjona D, Lomas J, Alonso ME, De Campos JM, Vaquero J, Isla A, Gutierrez M and Rey JA (2003b) Promoter hypermethylation of multiple genes in astrocytic gliomas. Int J Oncol 22:601-608.

Gonzalez-Gomez P, Bello MJ, Lomas J, Arjona D, Alonso ME, Aminoso C, De Campos JM, Vaquero J, Sarasa JL, Casartelli C and Rey JA (2003c) Epigenetic changes in pilocytic astrocytomas and medulloblastomas. Int $\mathrm{J}$ Mol Med 11:655-660.

Gonzalez-Gomez P, Bello MJ, Lomas J, Arjona D, Alonso ME, Aminoso C, Lopez-Marin I, Anselmo NP, Sarasa JL, Gutierrez M, Casartelli C and Rey JA (2003d) Aberrant methylation of multiple genes in neuroblastic tumours: Relationship with $M Y C N$ amplification and allelic status at 1p. European J Cancer 39:1478-1485.

Gonzalez-Gomez P, Bello MJ, Alonso ME, Lomas J, Arjona D, de Campos JM, Vaquero J, Isla A, Lassaletta L, Gutierrez M, Sarasa JL and Rey JA (2003e) CpG island methylation in 
sporadic and neurofibromatosis type 2-associated schwannomas. Clin Cancer Res 9:5601-5606.

Greger V, Debus N, Lohmann D, Hopping W, Passarge E and Horsthemke B (1994) Frequency and parental origin of hypermethylated $R B 1$ alleles in retinoblastoma. Hum Genet 94:491-496.

Hegi ME, Diserens AC, Gorlia T, Hamou MF, de Tribolet N, Weller M, Kros JM, Hainfellner JA, Mason W, Mariani L, Bromberg JE, Hau P, Mirimanoff RO, Cairncross JG, Janzer RC and Stupp R (2005) MGMT gene silencing and benefit from temozolomide in glioblastoma. $\mathrm{N}$ Engl $\mathrm{J}$ Med 352:997-1003.

Herman JG, Graff JR, Myohanen S, Nelkin BD and Baylin SB (1996) Methylation-specific PCR: A novel PCR assay for methylation status of $\mathrm{CpG}$ islands. Proc Natl Acad Sci USA 93:9821-9826.

Kleihues P and Cavenee WK (2000) Pathology and Genetics of Tumors of the Nervous System. World Health Organization Classification of Tumors. IARC Press, Lyon, 314 pp.

Kleihues P, Louis DN, Scheithauer BW, Rorke LB, Reifenberger G, Burger PC and Cavenee WK (2002) The WHO classification of tumors of the nervous system. J Neuropathol Exp Neurol 61:215-225.

Lomas J, Bello MJ, Arjona D, Gonzalez-Gomez P, Alonso ME, de Campos JM, Vaquero J, Ruiz-Barnes P, Sarasa JL, Casartelli C and Rey JA (2001) Analysis of $p 73$ gene in meningiomas with deletion at $1 \mathrm{p}$. Cancer Genet Cytogenet 129:88-91.

Lomas J, Amiñoso C, Gonzalez-Gomez P, Alonso ME, Arjona D, Lopez-Marin I, de Campos JM, Isla A, Vaquero J, Gutierrez M, Sarasa JL, Bello MJ and Rey JA (2004) Methylation status of TP73 in meningiomas. Cancer Genet Cytogenet 148:148-151.

Melki JR, Vincent PC and Clark SJ (1999) Concurrent DNA hypermethylation of multiple genes in acute myeloid leukemia. Cancer Res 59:3730-3740.

Merlo A, Herman JG, Mao L, Lee DJ, Gabrielson E, Burger PC, Baylin SB and Sidransky D (1995) 5' CpG island methylation is associated with transcriptional silencing of the tumour suppressor $p 16 / C D K N 2 / M T S 1$ in human cancers. Nat Med 1:686-692.

Morgenbesser SD, Williams BO, Jacks T and DePinho RA (1994) p53-dependent apoptosis produced by $\mathrm{Rb}$-deficiency in the developing mouse lens. Nature 371:72-74.

Mueller W, Hartmann C, Hoffmann A, Lanksch W, Kiwit J, Tonn J, Veelken J, Schramm J, Weller M, Wiestler OD, Louis DN and von Deimling Al (2002) Genetic signature of oligoastrocytomas correlates with tumor location and denotes distinct molecular subsets. Am J Pathol 161:313-319.

Nakamura M, Konishi N, Hiasa Y, Tsunoda S, Nakase H, Tsuzuki T, Aoki H, Sakitani H, Inui T and Sakaki T (1998) Frequent alterations of cell-cycle regulators in astrocytic tumors as detected by molecular genetic and immunohistochemical analyses. Brain Tumor Pathol 15:83-88.

Nakamura M, Yonekawa Y, Kleihues P and Ohgaki H (2001a) Promoter hypermethylation of the $R B 1$ gene in glioblastomas. Lab Invest 81:77-82.

Nakamura M, Watanabe T, Klangby U, Asker C, Wiman K, Yonekawa Y, Kleihues P and Ohgaki H (2001b) p14ARF deletion and methylation in genetic pathways to glioblastomas. Brain Pathol 11:159-168.
Nakamura M, Watanabe T, Yonekawa Y, Kleihues P and Ohgaki H (2001c) Promoter methylation of the DNA repair gene $M G M T$ in astrocytomas is frequently associated with $\mathrm{G}: \mathrm{C} \rightarrow \mathrm{A}: \mathrm{T}$ mutations of the TP53 tumor suppressor gene. Carcinogenesis 22:1715-1719.

Nishikawa R, Furnari FB, Lin H, Arap W, Berger MS, Cavenee WK and Su Huang HJ (1995) Loss of P16INK4 expression is frequent in high grade gliomas. Cancer Res 55:19411945.

Ohtani-Fujita N, Dryja TP, Rapaport JM, Fujita T, Matsumura S, Ozasa K, Watanabe Y, Hayashi K, Maeda K, Kinoshita S, Matsumura T, Ohnishi Y, Hotta Y, Takahashi R, Kato MV, Ishizaki K, Sasaki MS, Horsthemke B, Minoda K and Sakai $\mathrm{T}$ (1997) Hypermethylation in the retinoblastoma gene is associated with unilateral, sporadic retinoblastoma. Cancer Genet Cytogenet 98:43-49.

Park SH, Jung KC, Ro JY, Kang GH and Khang SK (2000) 5' $\mathrm{CpG}$ island methylation of $p 16$ is associated with absence of p16 expression in glioblastomas. J Korean Med Sci 15:555-559.

Rey JA, Bello MJ, Jiménez-Lara AM, Vaquero J, Kusak ME, de Campos JM, Sarasa JL and Pestaña A (1992) Loss of heterozygosity for distal markers on $22 \mathrm{q}$ in human gliomas. Int $\mathrm{J}$ Cancer 51:703-706.

Robertson KD and Jones PA (1998) The human ARF cell cycle regulatory gene promoter is a $\mathrm{CpG}$ island which can be silenced by DNA methylation and down-regulated by wildtype $p 53$. Mol Cell Biol 18:6457-6473.

Sakai T, Toguchida J, Ohtani N, Yandell DW, Rapaport JM and Dryja TP (1991) Allele-specific hypermethylation of the retinoblastoma tumor-suppressor gene. Am J Hum Genet 48:880-888.

Sanchez-Cespedes M, Esteller M, Wu L, Nawroz-Danish H, Yoo GH, Koch WM, Jen J, Herman JG and Sidransky D (2000) Gene promoter hypermethylation in tumors and serum of head and neck cancer patients. Cancer Res 60:892-895.

Sherr CJ (1996) Cancer cell cycles. Science 274:1672-1677.

Simpson DJ, Hibberts NA, McNicol AM, Clayton RN and Farrell WE (2000) Loss of $p R b$ expression in pituitary adenomas is associated with methylation of the $R B 1 \mathrm{CpG}$ island. Cancer Res 60:1211-1216.

Stirzaker C, Millar DS, Paul CL, Warnecke PM, Harrison J, Vincent PC, Frommer M and Clark SJ (1997) Extensive DNA methylation spanning the $R b$ promoter in retinoblastoma tumors. Cancer Res 57:2229-2237.

Tse JY, Ng HK, Lo KW, Chong EY, Lam PY, Ng EK, Poon WS and Huang DP (1998) Analysis of cell cycle regulators: pl6INK4A, pRb, and CDK4 in low- and high-grade meningiomas. Hum Pathol 29:1200-1207.

Walker C, du Plessis DG, Fildes D, Haylock B, Husband D, Jenkinson MD, Joyce KA, Broome J, Kopitski K, Prosser J, Smith T, Vinjamuri S and Warnke PC (2004) Correlation of molecular genetics with molecular and morphological imaging in gliomas with an oligodendroglial component. Clin Cancer Res 10:7182-7191.

Watanabe T, Nakamura M, Yonekawa Y, Kleihues P and Ohgaki (2001a) Promoter hypermethylation and homozygous deletion of the $p 14 A R F$ and p16INK4a genes in oligodendrogliomas. Acta Neuropathol 101:185-189.

Watanabe T, Yokoo H, Yokoo M, Yonekawa Y, Kleihues P and Ohgaki H (2001b) Concurrent inactivation of RB1 and TP53 
pathways in anaplastic oligodendrogliomas. J Neuropathol Exp Neurol 60:1181-1189.

Wolter M, Reifenberger J, Blaschke B, Ichimura K, Schmidt EE, Collins VP and Reifenberger G (2001) Oligodendroglial tumors frequently demonstrate hypermethylation of the CDKN2A (MTS1, p16INK4a), p14ARF, and CDKN2B (MTS2, p15INK4b) tumor suppressor genes. J Neuropathol Exp Neurol 60:1170-1180.

Yin D, Xie D, Hofmann WK, Miller CW, Black KL and Koeffler HP (2002) Methylation, expression, and mutation analysis of the cell cycle control genes in human brain tumors. Oncogene 21:8372-8378.

Zhang Y, Xiong Y and Yarbrough WG (1998) ARF promotes $M D M 2$ degradation and stabilizes p53: ARF-INK4a locus deletion impairs both the $R b$ and $p 53$ tumor suppression pathways. Cell 92:725-734.

Zlatescu MC, TehraniYazdi A, Sasaki H, Megyesi JF, Betensky RA, Louis DN and Cairncross JG (2001) Tumor location and growth pattern correlate with genetic signature in oligodendroglial neoplasms. Cancer Res. 61:6713-6715. Associate Editor: Emmanuel Dias Neto 